\title{
Editorial
}

\section{Sustainability for Shrinking Cities}

\author{
Dustin L. Herrmann ${ }^{1}$ * , William D. Shuster ${ }^{2}$, Audrey L. Mayer ${ }^{3}$ and Ahjond S. Garmestani ${ }^{2}$ \\ 1 Oak Ridge Institute for Science and Education Research Participant Program, \\ United States Environmental Protection Agency, Cincinnati, OH 45268, USA \\ 2 National Risk Management Research Laboratory, United States Environmental Protection Agency, \\ Cincinnati, OH 45268, USA; shuster.william@epa.gov (W.D.S.); garmestani.ahjond@epa.gov (A.S.G.) \\ 3 Department of Social Sciences \& School of Forest Resources and Environmental Sciences, \\ Michigan Technological University, Houghton, MI 49931, USA; almayer@mtu.edu \\ * Correspondence: herrmann.dustin@epa.gov; Tel.: +1-513-569-7937
}

Academic Editors: William D. Shuster, Audrey L. Mayer and Ahjond S. Garmestani Received: 31 August 2016; Accepted: 5 September 2016; Published: 7 September 2016

\begin{abstract}
Shrinking cities are widespread throughout the world despite the rapidly increasing global urban population. These cities are attempting to transition to sustainable trajectories to improve the health and well-being of urban residents, to build their capacity to adapt to changing conditions and to cope with major events. The dynamics of shrinking cities are different than the dynamics of growing cities, and therefore intentional research and planning around creating sustainable cities is needed for shrinking cities. We propose research that can be applied to shrinking cities by identifying parallel challenges in growing cities and translating urban research and planning that is specific to each city's dynamics. In addition, we offer applications of panarchy concepts to this problem. The contributions to this Special Issue take on this forward-looking planning task through drawing lessons for urban sustainability from shrinking cities, or translating general lessons from urban research to the context of shrinking cities.
\end{abstract}

Keywords: shrinking cities; panarchy; sustainable city; urban systems

\section{Introduction}

Humans are rapidly becoming an urban species, with greater populations in urban areas [1], increasing size of these urban areas, and increasing number of very large urban areas [2]. As a consequence, much of what we know about cities is focused on how they grow and take shape [2,3], the strains that their growth puts on city infrastructure [4,5], the consequences for human and other faunal-floral inhabitants of these cities and their surroundings [1,6-11], and governance which can either exacerbate or ease these transitions [12-15]. Indeed, political and economic incentives provide a powerful motivation for continuous growth [16]. However, concurrent with overall greater urbanization, some cities are in decline and experiencing abandoned urban areas due to loss of jobs and the economic base, environmental and infrastructure degradation, and a further corrosion of linked social conditions $[17,18]$.

We initiated this Special Issue because globalization of social, economic, and environmental capitals have sent cities into a state of structural and demographic flux. Observations of past urban dynamics indicate that cities commonly undergo contraction phases (e.g., $[19,20]$ ); though there remains a need to identify what a sustainable trajectory is for shrinking cities. The diversity of papers in this Special Issue reflect the many perspectives, disciplines and approaches that contribute to our knowledge of urban sustainability. The present trajectories of these urban areas undergoing contraction will continue to be modulated by social and economic forces, suggesting a great deal of potential for innovation and how to identify and deal with long-term contraction. Although some of these papers 
are not focused on shrinking cities, per se, they collectively highlight the dynamism of urbanization, with lessons for getting to sustainable trajectories in shrinking cities.

\section{Shrinking Cities: Definition}

Generally, a shrinking city can be considered one with a smaller population or economy compared with its past; although, even a threshold of time may invoke an arbitrary designation. Any definition of a shrinking city is confounded with the fact that cities are composed of parcels, streets and neighborhoods that can have different growth and shrinkage trajectories than that of the city in the aggregate. Many cities, including those experiencing rapid growth, will have areas that have lost significant levels of population and economic activity [21]. Regardless, the shifts in demography with shrinking forces a realignment of how infrastructure is used or abandoned [22]. The process of a slowing economy and population loss leads to low demand for housing and other urban infrastructure, a depleted tax base, decline in the availability of goods and services, and few resources with which to maintain municipal services, further decreasing any appeal to present or would-be residents. Once depopulation has started, there is commonly an accompanying increase in the proportion of abandoned or vacant structures and parcels [23,24].

A general goal for the shrinking city was suggested by Schilling and Logan [23] as "aligning a city's built environment with the needs of existing and future populations by adjusting the amount of land available for development". We add that development must be generalized to include changes in land use, such as set-asides, active (urban agriculture) and passive (green demolition) variants of green infrastructure, and abandonment in response to a persistent environmental condition (e.g., sea level rise). The form and spatial structure of a city exerts an influence on what a shrinking city will look like, and constrain what types and the extent of land use change (e.g., additional green space) that is possible [24]. What emerges is a unique social-ecological system with new challenges to sustainability science, ecology, and their application to urban planning for shrinking cities [25].

\section{The Urban Renaissance and Shrinking Cities}

In the U.S., the second half of the 20th century was marked by the urban decline era [17], which saw population loss from the city core via rapid suburbanization, which was facilitated by federal government backing of highway construction. This era exemplified the rejection of urban living and the degradation of urban neighborhoods. The abandonment of urban cores was accompanied by negative perceptions of cities that went unchecked [26]. One remarkable and recent shift in perception is from decline to the less value-laden concept of shrinking [17]. If some of the shrinking city phenomena in the U.S. is about past policy and practice that were unfavorable to the sustainable trajectories in urban cores, then a possibility for change is on the horizon. Urban living is growing in popularity and, in many cases, financial capital investment now focuses on urban areas and their redevelopment or in some contexts their "gentrification" [27]. In some cases, highways are being removed or reduced in size [28]. The shift in urbanization in favor of dense, and arguably traditional, urban neighborhoods can create the circumstances for stabilization in shrinking cities. In fact, most of the fastest-shrinking major U.S. cities appear to be experiencing a stabilization of their population levels (Figure 1). However, issues of gentrification must be addressed and socially-inclusive redevelopment is needed to create just and sustainable trajectories for shrinking cities [25,29]. Relatedly, there is also a need to recognize that many groups remained in the urban core and valued urban neighborhoods despite their neglect by government and planning priorities. 


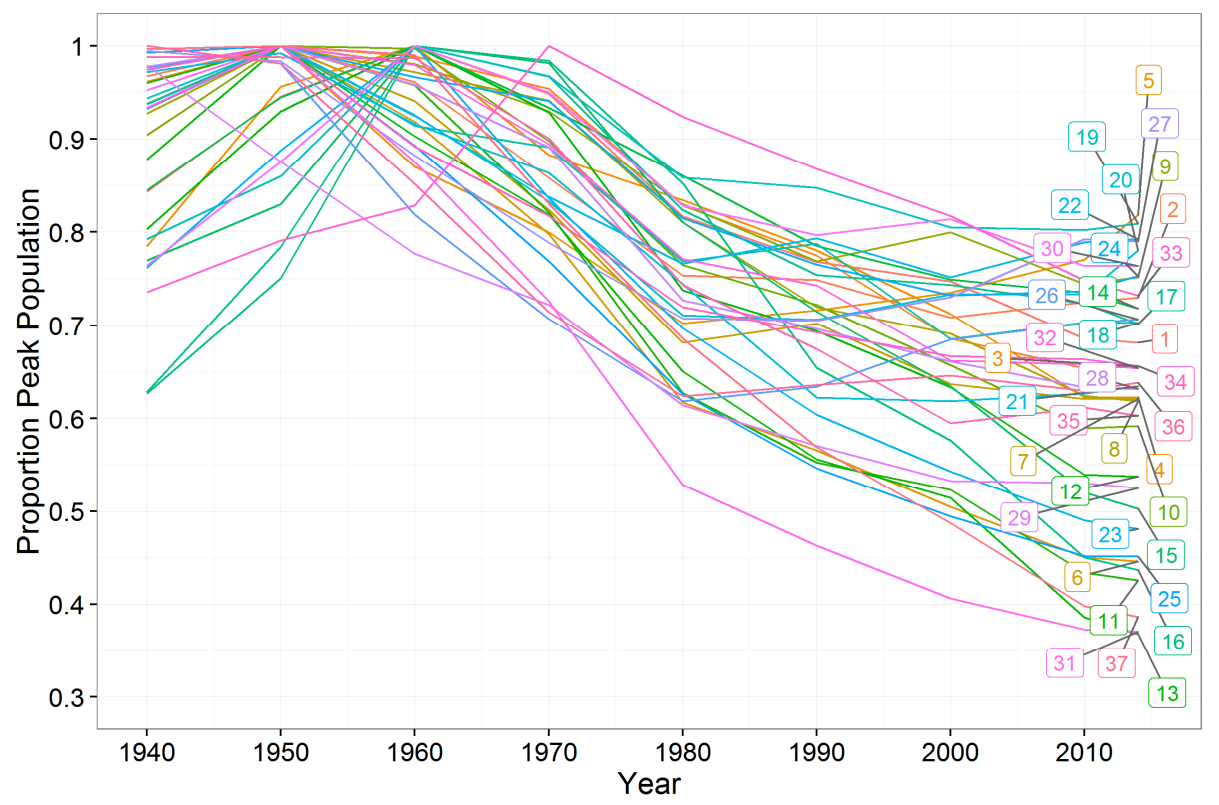

Figure 1. Population levels from 1940-2014 for U.S. shrinking cities as a proportion of their peak population, for cities of greater than 100,000 people at their peak population level. 1-Akron, $\mathrm{OH}$; 2-Albany, NY; 3-Baltimore, MD; 4-Birmingham, AL; 5-Boston, MA; 6-Buffalo, NY; 7-Camden, NJ; 8-Canton, OH; 9-Chicago, IL; 10-Cincinnati, OH; 11-Cleveland, OH; 12-Dayton, OH; 13-Detroit, MI; 14-Erie, PA; 15-Flint, MI; 16-Gary, IN; 17-Hammond, IN; 18-Hartford, CT; 19-Milwaukee, WI; 20-Minneapolis, MN; 21-Newark, NJ; 22-New Haven, CT; 23-Niagara Falls, NY; 24-Philadelphia, PA; 25-Pittsburgh, PA; 26-Providence, RI; 27-Reading, PA; 28-Rochester, NY; 29-Scranton, PA; 30-South Bend, IN; 31-St. Louis, MO; 32-Syracuse, NY; 33-Toledo, OH; 34-Trenton, NJ; 35-Utica, NY; 36-Wilmington, DE; 37-Youngstown, $\mathrm{OH}$.

\section{Transition to Sustainable Trajectories}

Sustainability is a tri-partite idea that includes social equity, economic stability, and environmental quality. Sustainability is also an inclusive vision, meaning positive quality of life outcomes must be met for people of different means and backgrounds [29]. The sustainable city is an idea that has been developed to guide transitions from current city modes, particularly the sanitary city [30,31]. The modernist, 'sanitary' city is the dominant city type in the developed world and a response to the poor urban conditions created by the growth of polluting urban industries in the 19th and early 20th centuries. It created centralized management of wastewater collection and treatment and segregated hazardous land uses to address pollution and human health issues [31].

The sanitary city is an instructive contrast to the largely conceptual impression of what might constitute the sustainable city. Contrasted with the sanitary city, the sustainable city: (1) prioritizes bottom-up solutions rather than top-down controls; (2) has governance structures that work across disciplinary/agency silos for a more integrative and comprehensive approach to city management; and (3) seeks to decentralize functions [30,31]. Other aspects of the sustainable city include: creating a more circular metabolism where the city relies on fewer inputs by internally cycling materials and energy; removing hazards (e.g., air pollution) as opposed to separating hazardous land uses (e.g., polluting industry) from residential areas; building public-private partnerships to manage municipal functions; and bringing together residents and experts in matters of city planning and management $[30,31]$.

Many researchers utilize a complex systems approach for sustainable cities which is applicable to a dynamic city (e.g., [15]). Although the same theories and frameworks apply to a range of urban dynamics, a shrinking city will have different challenges than growing cities in getting to sustainable trajectories. A productive route for research is to identify parallel sustainability challenges 
in shrinking versus growing cities (Table 1). In doing so, we can identify the theory and techniques for understanding urban systems that will translate our knowledge between growing and shrinking cities. This approach also has the advantage of using theory and techniques that work at different and meaningful scales.

Table 1. Parallel challenges faced by growing and shrinking cities in navigating to sustainable trajectories.

\begin{tabular}{cc}
\hline \multicolumn{2}{c}{ Sustainability Challenges } \\
\hline Growing Cities & Shrinking Cities \\
\hline Loss of green space & Abundance of green space \\
Increasing cost of living & Inadequate income options \\
Overburdened infrastructure & Underutilized infrastructure \\
Sprawl & De-densification \\
Environmental impacts & Pollution legacies \\
Time for social network to form & Social fragmentation \\
Suburban frontiers & Built legacy \\
Gentrification & Abandonment \\
\hline
\end{tabular}

One significant difference between growing and shrinking cities is the proportion of green space providing ecosystem services which can help accomplish sustainable city goals [32]. Growing cities experience a net loss of green space, as there is high competition for space with other urban uses. Shrinking cities conversely are faced with an increasing extent of green space, typically in the form of vacant land. This green space can be a burden on shrinking cities and their residents, as in many cases the emergent green space is unmanaged, functions as blight, and does not generate revenue. However, the emerging green space could provide ecosystem services such as water filtration and carbon sequestration, and given appropriate governance are a resource shrinking cities can use to transition to sustainable trajectories [25].

\section{Dynamics of Urban Systems}

The development of sustainable trajectories for shrinking cities needs an integrative, dynamic approach. One way to consider the dynamics of shrinking cities is via panarchy [33]. Panarchy conceptualizes social-ecological systems, such as urban systems, as a hierarchy of adaptive cycles [34]. Changes in lower-order cycles (e.g., residential foreclosures) can create the circumstances for change (a "revolt") in a higher-order cycle (e.g., blighted neighborhoods and reduced revenues), which subsequently sustain an internal memory to keep lower-order cycles in previous states (Figure 2).

Urban systems generally have spatial heterogeneity among their social and ecological infrastructures [35]. The physical configuration of the environment (e.g., topography, transportation corridors) can play a key role in the flow of human and commercial capitals [15]. For example, zoning in cities is determined at the municipal scale by zoning regulations, but is also affected by business interests and national economies [36]. The heterogeneity, or patchiness, in cities is the basis for the nested adaptive cycles of panarchy that maintain the gradients driving transitions to sustainable trajectories in shrinking cities. Further, city growth rates are dependent upon the size of a city, and as urban social-ecological systems, are influenced by hierarchical, historic and generally site-specific dynamics that are often random, differentiating cities from the straightforward development pattern of well-understood physical systems [15]. For example, the growth of cities in the southeastern United States has been shown to be dependent upon mean household income, and the percentage of the population of a city with a college degree [37]. These different dimensions of the urban experience can be interpreted in an objective manner to delineate scale within and among cities [38], and represent levels in a panarchy of urban systems, wherein cities on similar trajectories largely remain in their 
original size classes. There are exceptions, however, as some cities have experienced tremendous growth (e.g., Phoenix), while others have experienced precipitous decline (e.g., Cleveland).

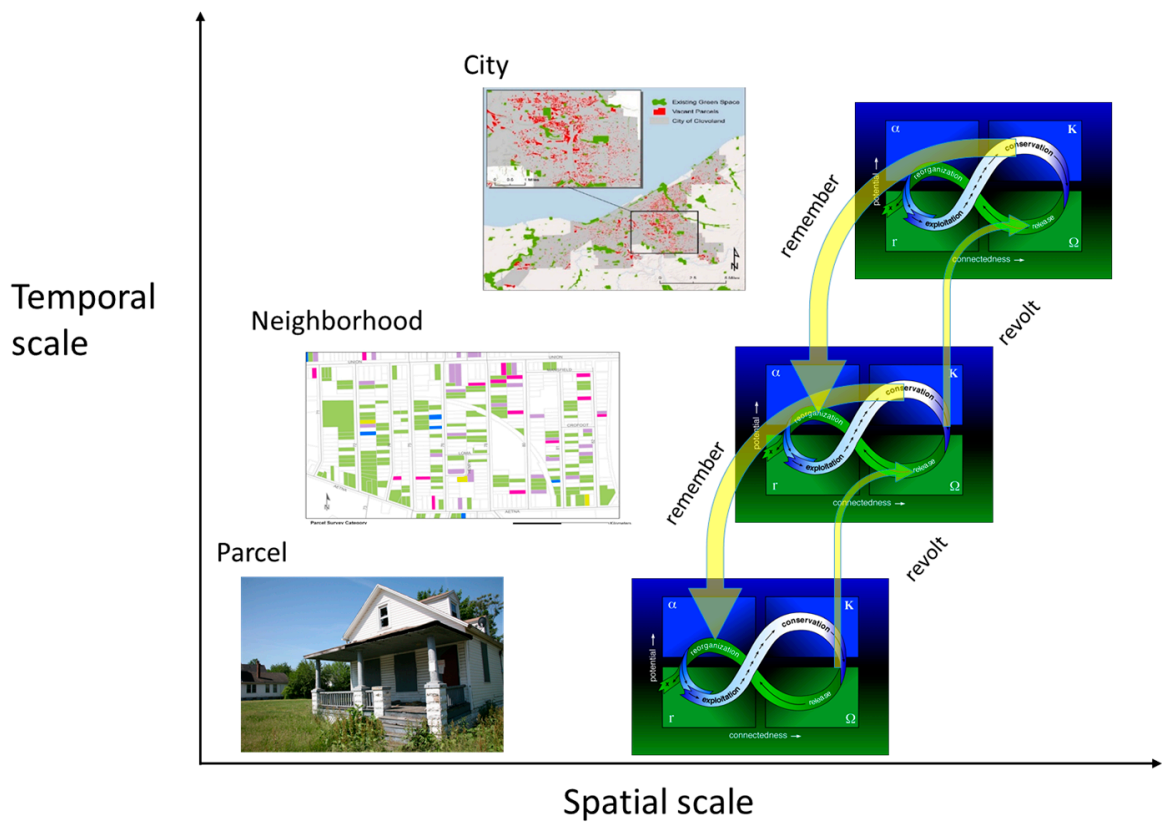

Figure 2. A conceptualization of panarchy for shrinking cities adapted from Allen et al. [34].

Panarchy also exists within an individual city via its social-ecological conditions (Figure 2). A social-ecological system may be a candidate for transformation if it is in a degraded state (e.g., economically depressed city). Leadership, networks, learning and trust are key aspects of the transformative capacity of a social-ecological system [39]. Variables that characterize dimensions of the urban social-ecological system at different scales and trajectories also exhibit different speeds along these trajectories, which in turn manifests as scale-dependent structure [33]. For urban systems, growth rate, governance, and infrastructure, are respectively, fast, medium, and slow variables. Slow variables largely determine the resilience of a system [40], highlighting the role of infrastructure in understanding the sustainable trajectory of a city experiencing contraction. For shrinking cities (e.g., Cleveland) that wish to slow decline and stabilize for sustainability, catalyzing change in infrastructure from gray to green infrastructure is a path to facilitate transformation. For a shrinking city like Cleveland, the decline of the city created an opportunity to transform the city to a sustainable pathway that is still ongoing. In particular, a transition from gray to green infrastructure is possible due to an abundance of vacant land throughout the city [25,32]. Vacant land is being used for urban agriculture, wildlife corridors, recreational areas, habitat for pollinators, and as green infrastructure (most important for transformation) to mimic the natural hydrologic cycle and reduce stormwater overflows [32]. The visual aesthetics of these green infrastructure projects are incredibly important to residents, and thus the social value of these areas should not be underestimated [41]. On the other hand, the basic infrastructure of our cities is unusually difficult to transform, due to the necessity of massive investments in updating infrastructure that are often politically unpopular, presenting tremendous inertia to its overhaul [42].

\section{Synopsis of Contributions}

We have provided an overview of the circumstances of the shrinking city, a theoretical foundation for this dynamic in urban systems, and now highlight contributions to this Special Issue that study various aspects of this broad matter. Although impossible to address comprehensively, the contributions all view different dimensions of shrinking cities. Several contributions discuss 
the positive potentials in reimagining shrinking city problems. For example, the issue of legacy soil lead burden in vacant lands is examined by Schwarz et al. [43] and offers a new framing of the problem by promoting human (learning and knowledge), social (urban gardening), and technical (soil testing as a data feedback) capitals to mitigate against soil lead availability, and leverage available natural resources toward urban agroecosystems that benefit local communities. Winkler et al. [44] investigates how human (art) and energy (geothermal) capitals may re-align the economics of making a living in a remote north central US town that lost its metal mining enterprise in the late 1960s. Ročak et al. [45] explores how residents experience shrinking in the Dutch city of Heerlen and examine through interviews three social capital indicators among residents: resources, empowerment, and participation. Collectively, these three contributions connect tangibly to the source of problems for identifying pathways to sustainability.

Many contributors covered how vacant land affects social and ecological outcomes in shrinking cities. Kim [46] reviews how municipalities and other organizations are utilizing urban vacant land and develops a typology to guide conceptual understanding of the diversity of vacant land types in cities. Gulachenski et al. [47] discusses the urban greening that is happening as a consequence of "counter-urbanization" in shrinking cities; this trend has great potential for generating ecosystem disservices, particularly public health risks as a result of greater exposure to vector- and water-borne pathogens. Bloetscher et al. [48] show how sea level rise has many of the same outcomes shrinking cities experience through population loss, such as compromised infrastructure and new public health risks experienced by vulnerable populations.

Finally, three contributions discuss how urban dynamics create or have consequences for shrinking cities. Meléndez-Ackerman et al. [49] examines residential yard management choices in San Juan, which is starting to exhibit shrinking in some neighborhoods. The differences in how residential landscapes are managed in occupied lots across regions may indicate a potential for differences in how vacant land is managed as well. Nam et al. [50] looks at housing vacancy throughout Korea and examines in-depth the correlated drivers in a single province. The authors found an excess of construction activity has led to a large number of apartment vacancies. Allen et al. [51] examines resilience in mid-sized cities. The paper argues that mid-size cities, shrinking or growing, are unique compared to large cities because they are more reliant on local ecosystem services. As such, a strategy for countering shrinking in mid-size cities may be acknowledging and leveraging this reliance for greater flexibility.

\section{Conclusions}

The contributions to this Special Issue add to the layers and nuance in understanding the dynamics of shrinking cities, information that is necessary to guide ongoing development along sustainable trajectories. Further research on shrinking cities is needed for two key reasons that are covered in this feature. First, shrinking is a common condition for cities around the world, and will likely continue to be so as cities age in this unprecedented era of economic change and human mobility, especially as this affects commerce and the concentration of development and wealth. Second, the processes of shrinkage can create unique challenges to and opportunities for urban sustainability that a broad research agenda on cities generally may not address. With regard to urban sustainability, shrinking cities offer a powerful contrast to growing cities that highlight a need for contextualized understanding of urban systems in this regard. Improved understanding will require situating the concepts and definitions of shrinking into theories such as panarchy that work across scales and relationships. Therefore, we recommend using the perspectives advanced in this Special Issue as another starting point, to inspire productive research agendas on shrinking cities and their development along sustainable trajectories. 
Acknowledgments: Partial support was provided to D.L. Herrmann through an appointment to the research participation program with the Oak Ridge Institute for Science and Education through the US Department of Energy and US Environmental Protection Agency. The views expressed in this article are strictly the opinions of the authors and in no manner represent or reflect current or planned policy by the US Environmental Protection Agency or other Federal agencies.

Author Contributions: All authors contributed to the writing of the paper.

Conflicts of Interest: The authors declare no conflict of interest.

\section{References}

1. Pain, S. The rise of the urbanite. Nature 2016, 531, S64-S66. [CrossRef] [PubMed]

2. Georg, I.; Blaschke, T.; Taubenbock, H. New spatial dimensions of global cityscapes: From reviewing existing concepts to a conceptual spatial approach. J. Geogr. Sci. 2016, 26, 355-380. [CrossRef]

3. Batty, M. The size, scale, and shape of cities. Science 2008, 319, 769-771. [CrossRef] [PubMed]

4. Li, E.; Endter-Wada, J.; Li, S. Characterizing and contextualizing the water challenges of megacities. J. Am. Water Resour. Assoc. 2015, 51, 589-613. [CrossRef]

5. Gaines, J.M. Water potential. Nature 2016, 531, S61-S63. [CrossRef] [PubMed]

6. Grimm, N.B.; Faeth, S.H.; Golubiewski, N.E.; Redman, C.L.; Wu, J.; Bai, X.; Briggs, J.M. Global change and the ecology of cities. Science 2008, 319, 756-760. [CrossRef] [PubMed]

7. Abbott, A. Urban decay. Nature 2012, 490, 162-164. [CrossRef] [PubMed]

8. Kumar, P.; Morawska, L.; Birmili, W.; Passonen, P.; Hu, M.; Kulmala, M.; Harrison, R.M.; Norford, L.; Britter, R. Ultrafine particles in cities. Environ. Int. 2014, 66, 1-10. [CrossRef] [PubMed]

9. Stanley, M.C.; Beggs, J.R.; Bassett, I.E.; Burns, B.R.; Dirks, K.N.; Jones, D.N.; Linklater, W.L.; Macinnis-Ng, C.; Simcock, R.; Souter-Brown, G.; et al. Emerging threats in urban ecosystems: A horizon scanning exercise. Front. Ecol. Environ. 2015, 13, 553-560. [CrossRef]

10. Eisenstein, M. Poverty and pathogens. Nature 2016, 531, S61-S63. [CrossRef] [PubMed]

11. Huang, L.; Yan, L.J.; Wu, J.G. Assessing urban sustainability of Chinese megacities: 35 years after the economic reform and open-door policy. Landsc. Urban Plan. 2016, 145, 57-70. [CrossRef]

12. Barrington-Leigh, C.; Millard-Ball, A. A century of sprawl in the United States. Proc. Natl. Acad. Sci. USA 2015, 112, 8244-8249. [CrossRef] [PubMed]

13. Estoque, R.C.; Murayama, Y. Intensity and spatial pattern of urban land changes in the megacities of Southeast Asia. Land Use Policy 2015, 48, 213-222. [CrossRef]

14. Deweerdt, S. The urban downshift. Nature 2016, 531, S52-S53. [CrossRef] [PubMed]

15. Pollock, K. Urban physics. Nature 2016, 531, S64-S66. [CrossRef] [PubMed]

16. Schindler, S. Detroit after bankruptcy: A case of degrowth machine politics. Urban Stud. 2016, 53, 818-836. [CrossRef]

17. Beauregard, R.A. Urban population loss in historical perspective: United States, 1820-2000. Environ. Plan. A 2009, 41, 514-528. [CrossRef]

18. Martinez-Fernandez, C.; Audirac, I.; Fol, S.; Cunningham-Sabot, E. Shrinking cities: Urban challenges of globalization. Int. J. Urban Reg. Res. 2012, 36, 213-225. [CrossRef] [PubMed]

19. Cowgill, G.L. Origins and development of urbanism: Archaeological perspectives. Annu. Rev. Anthropol. 2004, 33, 525-549. [CrossRef]

20. Heckenberger, M.J.; Russell, J.C.; Fausto, C.; Toney, J.R.; Schmidt, M.J.; Pereira, E.; Franchetto, B.; Kuikuro, A. Pre-Columbian urbanism, anthropogenic landscapes, and the future of the Amazon. Science 2008, 321, 1214-1217. [CrossRef] [PubMed]

21. Kingsley, G.T.; Pettit, K.L.S. Population Growth and Decline in City Neighborhoods; Urban Institute: Washington, DC, USA, 2002.

22. Blanco, H.; Alberti, M.; Olshansky, R.; Chang, S.; Wheeler, S.M.; Randolph, J.; London, J.B.; Hollander, J.B.; Pallagst, K.; Schwarz, T.; et al. Shaken, shrinking, hot, impoverished and informal: Emerging research agendas in planning. Prog. Plan. 2009, 72, 195-250. [CrossRef]

23. Schilling, J.; Logan, J. Greening the Rust Belt: A green infrstructure model for right sizing America's shrinking cities. J. Am. Plan. Assoc. 2008, 74, 451-466. [CrossRef] 
24. Schetke, S.; Haase, D. Mulit-criteria assessment of socio-environmental aspects in shrinking cities: Experiences from eastern Germany. Environ. Impact Assess. Rev. 2008, 28, 483-503. [CrossRef]

25. Herrmann, D.L.; Schwarz, K.; Shuster, W.D.; Berland, A.; Chaffin, B.C.; Garmestani, A.S.; Hopton, M.E. Ecology for the shrinking city. Bioscience 2016. [CrossRef]

26. Glaeser, E.L. Why Economists Still Like Cities; City Journal: New York, NY, USA, 1996; p. 7.

27. Gamble, D.; Heyda, P. Rebuilding the American City: Design and Strategy for the 21st Century Urban Core; Routledge: New York, NY, USA, 2016.

28. Semuels, A. Highways Destroyed America's Cities: Can Tearing Them down Bring Revitalization?; The Atlantic: Washington, DC, USA, 2015.

29. Agyeman, J. Introducing Just Sustainabilities: Policy, Planning and Practice; Zed Books: London, UK, 2013.

30. Pincetl, S. From the sanitary city to the sustainable city: Challenges to institutionalising biogenic (nature's services) infrastructure. Local Environ. 2010, 15, 43-58. [CrossRef]

31. Pickett, S.T.A.; Boone, C.G.; McGrath, B.P.; Cadenasso, M.L.; Childers, D.L.; Ogden, L.A.; McHale, M.; Grove, J.M. Ecological science and transformation to the sustainable city. Cities 2013, 32, S10-S20. [CrossRef]

32. Green, O.O.; Garmestani, A.S.; Albro, S.; Ban, N.C.; Berland, A.; Burkman, C.E.; Gardiner, M.M.; Gunderson, L.; Hopton, M.E.; Schoon, M.L.; et al. Adaptive governance to promote ecosystem services in urban green spaces. Urban Ecosyst. 2016, 19, 77-93. [CrossRef]

33. Gunderson, L.H.; Holling, C.S. Panarchy: Understanding Transformations in Human and Natural Systems; Island Press: Washington, DC, USA, 2002.

34. Allen, C.R.; Angeler, D.G.; Garmestani, A.S.; Gunderson, L.H.; Holling, C.S. Panarchy: Theory and application. Ecosystems 2014, 17, 578-589. [CrossRef]

35. Grimm, N.B.; Grove, J.M.; Pickett, S.T.A.; Redman, C.L. Integrated approaches to long-term studies of urban ecological systems. Bioscience 2000, 50, 571-584. [CrossRef]

36. Garmestani, A.S.; Allen, C.R.; Bessey, K.M. Time-series analysis of clusters in city size distributions. Urban Stud. 2005, 42, 1507-1515. [CrossRef]

37. Eason, T.; Garmestani, A.S. Cross-scale dynamics of a regional urban system through time. Reg. Dev. 2012, $36,55-77$.

38. Garmestani, A.S.; Allen, C.R.; Gunderson, L.H. Panarchy: Discontinuities reveal similarities in the dynamic system structure of ecological and social systems. Ecol. Soc. 2009, 14, 15.

39. Gunderson, L.H.; Carpenter, S.R.; Folke, C.; Olsson, P.; Peterson, G.D. Waters RATs (resilience, adaptability, and transformability) in lake and wetland social-ecological systems. In Exploring Resilience in Social-Ecological Systems; Walker, B.H., Anderies, J., Kinzig, A., Ryan, P., Eds.; CSIRO Press: Collingwood, Australia, 2006; pp. 61-73.

40. Allen, C.R.; Holling, C.S. Discontinuities in Ecosystems and Other Complex Systems; Columbia University Press: New York, NY, USA, 2008.

41. Baptiste, A.K.; Foley, C.; Smardon, R. Understanding urban neighborhood differences in willingness to implement green infrastructure measures: A case study of Syracuse, NY. Landsc. Urban Plan. 2015, 136, 1-12. [CrossRef]

42. Brown, R.R.; Farrelly, M.A.; Loorbach, D.A. Actors working the institutions in sustainability transitions: The case of Melbourne's stormwater management. Glob. Environ. Chang. 2013, 23, 701-718. [CrossRef]

43. Schwarz, K.; Cutts, B.B.; London, J.K.; Cadenasso, M.L. Growing gardens in shrinking cities: A solution to the soil lead problem? Sustainability 2016, 8, 141. [CrossRef]

44. Winkler, R.; Oikarinen, L.; Simpson, H.; Michaelson, M.; Sanchez Gonzalez, M. Boom, bust, and beyond: Arts and sustainability in Calumet, Michigan. Sustainability 2016, 8, 284. [CrossRef]

45. Ročak, M.; Hospers, G.-J.; Reverda, N. Searching for social sustainability: The case of the shrinking city of Heerlen, The Netherlands. Sustainability 2016, 8, 382. [CrossRef]

46. Kim, G. The public value of urban vacant land: Social responses and ecological value. Sustainability 2016, 8, 486. [CrossRef]

47. Gulachenski, A.; Ghersi, B.M.; Lesen, A.E.; Blum, M.J. Abandonment, ecological assembly and public health risks in counter-urbanizing cities. Sustainability 2016, 8, 491. [CrossRef]

48. Bloetscher, F.; Polsky, C.; Bolter, K.; Mitsova, D.; Palbicke Garces, K.; King, R.; Cosio Carballo, I.; Hamilton, K. Assessing potential impacts of sea level rise on public health and vulnerable populations in southeast Florida and providing a framework to improve outcomes. Sustainability 2016, 8, 315. [CrossRef] 
49. Meléndez-Ackerman, E.J.; Nytch, C.J.; Santiago-Acevedo, L.E.; Verdejo-Ortiz, J.C.; Santiago-Bartolomei, R.; Ramos-Santiago, L.E.; Muñoz-Erickson, T.A. Synthesis of household yard area dynamics in the city of San Juan using multi-scalar social-ecological perspectives. Sustainability 2016, 8, 481. [CrossRef]

50. Nam, J.; Han, J.; Lee, C. Factors contributing to residential vacancy and some approaches to management in Gyeonggi Province, Korea. Sustainability 2016, 8, 367. [CrossRef]

51. Allen, C.R.; Birge, H.E.; Bartlelt-Hunt, S.; Bevans, R.A.; Burnett, J.L.; Cosens, B.A.; Cai, X.; Garmestani, A.S.; Linkov, I.; Scott, E.A.; et al. Avoiding decline: Fostering resilience and sustainability in midsize cities. Sustainability 2016, 8, 844. [CrossRef]

(C) 2016 by the authors; licensee MDPI, Basel, Switzerland. This article is an open access article distributed under the terms and conditions of the Creative Commons Attribution (CC-BY) license (http:/ / creativecommons.org/licenses/by/4.0/). 